$\begin{array}{ll}\text { ISSN Cetak } & : 2087-0434 \\ \text { E-ISSN } & : 2599-0810\end{array}$

\title{
PERBANDINGAN KINERJA KEUANGAN BANK BUMN DAN BANK SWASTA NASIONAL (Studi Pada Bank Umum Konvensional Yang Terdaftar pada OJK Pada Tahun 2016-2019)
}

\author{
Febrian Indah Asmiyanti ${ }^{1)}$, Rr. Hawik Indiworo ${ }^{\text {2), }}$, Ratih Hesty Utami P ${ }^{3)}$ \\ ${ }^{1)}$ Prodi Manajemen - Universitas PGRI Semarang \\ 2) Prodi Manajemen - Universitas PGRI Semarang \\ 3) Prodi Manajemen - Universitas PGRI Semarang \\ E-mail: hawikervina@upgris.ac.id
}

\begin{abstract}
Abstrak
Penelitian ini bertujuan untuk mengetahui ada tidaknya perbedaan yang signifikan kinerja keuangan antara Bank BUMN dan Bank Swasta Nasional di Otoritas Jasa Keuangan (OJK) pada tahun 2016-2019. Dalam penelitian ini teknik pengumpulan data menggunakan dua metode yaitu dokumentasi dan studi pustaka. Data tersebut menggunakan data sekunder yang ada di Otoritas Jasa Keuangan (OJK), yaitu berupa laporan publikasi neraca dan laba rugi. Jenis metode penelitian yang dilakukan yaitu metode penelitian komparatif, yaitu membandingkan antara dua kelompok bank. Metode pemilihan sampel dilakukan dengan cluster sampling, yaitu teknik yang membentuk beberapa cluster dari hasil penyeleksian sebagian individu dari sebuah populasi. Menggunakan teknik uji beda dua sisi dan perhitungan uji t hitung yang digunakan alat bantu perangkat lunak komputer program SPSS. Hasil penelitian menunujukkan tidak terdapat perbedaan kinerja keuangan Bank BUMN dan Bank Swasta Nasional dilihat dari ROA, ROE, CAR, dan NIM tahun 2016-2019. Terdapat perbedaan kinerja keuangan Bank BUMN dan Bank Swasta Nasional dilihat dari ROE tahun 2018.
\end{abstract}

Kata kunci : CAR, Kinerja Keuangan, NIM, ROA, ROE

\section{PENDAHULUAN}

Bank merupakan lembaga keuangan yang mempunyai peranan penting didalam pertumbuhan perekonomian pada suatu negara. Pada hakikatnya bank adalah lembaga keuangan yang merupakan lembaga intermediasi, instrument keuangan seperti saham, obligasi, surat berharga pasar uang, dan pasar sebagai tempat perdagangan instrument keuangan seperti bursa saham dan pasar uang antar bank (Kasmir, 2012).

Undang-undang No.10 Tahun 1998 tentang Perbankan, mendefinisikan bank sebagai badan usaha yang menghimpun dana dari masyarakat dalam bentuk simpanan dan menyalurkannya kepada masyarakat, dalam bentuk kredit dan atau 
bentuk lainnya dalam rangka meningkatkan taraf hidup rakyat banyak. Hal ini dikarenakan perbankan merupakan salah satu dari sistem keuangan yang berfungsi sebagai financial intermediary, yaitu suatu lembaga yang mempunyai peran untuk mempertemukan antara pemilik dan pengguna dana.

Laporan keuangan pada perbankkan, menunjukkan kinerja keuangan yang telah dicapai perbankan pada suatu waktu. Kinerja keuangan tersebut dapat diketahui dengan menghitung rasio-rasio keuangan, sehingga dapat mengetahui kinerja tersebut dengan menggunakan analisis rasio, yakni rasio likuiditas, solfabilitas, rentabilitas, dan efisiensi operasional. Analisis rasio ini merupakan teknis analisis untuk mengetahui hubungan antara pos-pos tertentu dalam neraca maupun laba rugi bank secara individual maupun bersama-sama.(Abdullah, 2008).

\section{Tabel 1}

Rata-rata Kinerja Keuangan Bank BUMN

\begin{tabular}{lllll}
\hline Rasio Keuangan & $\mathbf{2 0 1 6}$ & $\mathbf{2 0 1 7}$ & $\mathbf{2 0 1 8}$ & $\mathbf{2 0 1 9}$ \\
\hline ROA & $2,54 \%$ & $2,80 \%$ & $2,94 \%$ & $2,82 \%$ \\
ROE & $16,83 \%$ & $18,36 \%$ & $19,66 \%$ & $17,93 \%$ \\
CAR & $20,15 \%$ & $19,99 \%$ & $19,12 \%$ & $20,15 \%$ \\
\hline NIM & $5,55 \%$ & $5,19 \%$ & $4,95 \%$ & $4,86 \%$
\end{tabular}

Sumber: Data diolah, 2021

Dari tabel diatas menunjukan kinerja keuangan perbankan Bank BUMN mengalami perubahan dari tahun-ketahun. Hal ini ditunjukkan oleh rasio ROA mengalami peningkatan pada tahun 2016 sampai 2018 dan di tahun 2019 mengalami penurunan drastis sebesar 2,82\%, rasio ROE mengalami peningkatan dari tahun 2016 sampai 2018 dan di tahun 2019 mengalami penurunan sebesar 17,93\%, rasio CAR mengalami ketidakstabilan dari tahun 2016-2019, dan rasio NIM mengalami penurunan dari tahun 2016 sampai 2019. 


$\begin{array}{ll}\text { ISSN Cetak } & : 2087-0434 \\ \text { E-ISSN } & : 2599-0810\end{array}$

Tabel 2

Rata-rata Kinerja Keuangan Bank Swasta Nasional

\begin{tabular}{lllll}
\hline Rasio Keuangan & $\mathbf{2 0 1 6}$ & $\mathbf{2 0 1 7}$ & $\mathbf{2 0 1 8}$ & $\mathbf{2 0 1 9}$ \\
\hline ROA & $2,32 \%$ & $1,88 \%$ & $1,76 \%$ & $1,84 \%$ \\
ROE & $15,53 \%$ & $12,21 \%$ & $9,84 \%$ & $8,91 \%$ \\
CAR & $21,43 \%$ & $18,12 \%$ & $19,43 \%$ & $20,97 \%$ \\
\hline NIM & $3,62 \%$ & $3,48 \%$ & $4,3 \%$ & $3,64 \%$ \\
\hline
\end{tabular}

Sumber: Data diolah, 2021

Dari tabel diatas, kinerja keuangan perbankan Bank Swasta Nasional mengalami perubahan dari tahun-ketahun. Hal ini ditunjukkan oleh rasio ROA mengalami ketidakstabilan pada tahun 2016 sampai 2019, rasio ROE mengalami penurunan dari tahun 2016 sampai 2019, rasio CAR terus meningkat dari tahun 2016-2019 dan rasio NIM mengalami ketidakstabilan dari tahun 2016 sampai 2019.

Berdasarkan uraian yang telah dijelaskan diatas, maka menjadi inti permasalahan ini dapat dirumuskan sebagai berikut, Apakah ada perbedaan kinerja keuangan antara bank BUMN dengan Bank Umum Swasta Nasional yang terdaftar di OJK? Sedangkan tujuan yang ingin dicapai dalam penelitian ini adalah untuk menganalisis perbedaan kinerja keuangan antara bank BUMN dengan Bank Umum Swasta Nasional yangterdaftar di OJK.

\section{METODE PENELITIAN}

Menurut Sugiyono (2015: 3), mengatakan "Metode penelitian adalah sebagai cara ilmiah untuk mendapatkan data dengan tujuan dan kegunaan tertentu". Jenis metode penelitian yang dilakukan yaitu metode penelitian komparatif, yaitu membandingkan. Penelitian ini bermaksud untuk mengetahui apakah antara dua kelompok bank ada perbedaan variabel yang diteliti. Dalam penelitian ini peneliti membandingkan kinerja keuangan Bank BUMN dan Bank Swasta Nasional periode 2016-2019. Pada penelitian ini yang menjadi populasi adalah Bank Umum Konvensional di Otoritas Jasa Keuangan,. Sedangkan sampel penelitian menggunakan 12 Bank, yang terdiri dari 3 Bank BUMN dan 9 Bank Swasta Nasional. 


$\begin{array}{ll}\text { ISSN Cetak } & : 2087-0434 \\ \text { E-ISSN } & : 2599-0810\end{array}$

Analisis data yang digunakan untuk menguji ada tidaknya perbedaan kinerja keuangan antara bank BUMN dengan Bank Swasta Nasional digunakan teknik analisis kesamaan dua rata-rata atau uji dua pihak ( $\mathrm{t}$ - test). Dengan rumus sebagai berikut:

$$
\mathrm{t}=\frac{\overline{X_{1}}-\overline{X_{2}}}{\sqrt{\left\{\frac{\left(n_{1}-1\right) s_{1}^{2}+\left(n_{2}-1\right) s_{2}^{2}}{\left(n_{1}+n_{2}-2\right)}\right\}\left\{\frac{1}{n_{1}}+\frac{1}{n_{2}}\right\}}}
$$

\section{Keterangan:}

$\overline{X_{1}} \quad$ : Mean kinerja Bank BUMN dilihat dari ROA, ROE, CAR, NIM

$\overline{X_{2}}$ : Mean kinerja Bank Swasta Nasional dilihat dari ROA, ROE, CAR, NIM

$n_{1} \quad$ : Banyaknya Bank BUMN yang diamati

$n_{2} \quad$ : Banyaknya Bank Swasta Nasional yang diamati

$s_{1} \quad$ : Deviasi standar kinerja Bank BUMN

$s_{2} \quad$ : Deviasi standar kinerja Bank Swasta Nasional

\section{HASIL DAN PEMBAHASAN}

Berdasarkan hasil analisis perbandingan kinerja keuangan Bank BUMN dan Bank Swasta Nasional selama 4 tahun dari 2016-2019, maka hasil tersebut sebagai berikut:

Tabel 3

Hasil Perbandingan Kinerja Keuangan Bank BUMN Dan Bank Swasta Nasional

\begin{tabular}{lcccc}
\hline & $\mathbf{2 0 1 6}$ & $\mathbf{2 0 1 7}$ & $\mathbf{2 0 1 8}$ & $\mathbf{2 0 1 9}$ \\
\hline ROA & 1,2185 & 1,3196 & 1,8261 & 1,6776 \\
ROE & 0,1684 & 2,1784 & 3,1567 & 0,5472 \\
CAR & 1,1749 & 1,0225 & $-0,1155$ & $-0,3383$ \\
\hline NIM & 1,7489 & 1,4776 & 0,4993 & 1,7122 \\
\hline
\end{tabular}

Sumber: Data Diolah, 2021

Berdasarkan data yang telah dihitung, untuk membandingkan kinerja keuangan Bank BUMN dan Bank Swasta Nasional dilakukan dengan uji beda ratarata dua sisi dengan hasil $\mathrm{t}$ tabel sebesar 2,228, penentuan kriteria pengujian:

$\mathrm{H}_{0}$ diterima apabila $\quad:-2,228 \leq \mathrm{t}_{\text {hitung }} \leq 2,228$

$\mathrm{H}_{0}$ ditolak apabila $\quad: \mathrm{t}_{\text {hitung }}>2,228$ atau $\mathrm{t}_{\text {hitung }}<-2,228$ 
Maka dapat disimpulkan sebagai berikut:

1) Jika $\mathrm{H}_{0}$ diterima berarti tidak ada perbedaan kinerja keuangan Bank BUMN dan Bank Swasta Nasional pada tahun 2016-2019 dilihat dari ROA, ROE, CAR, dan NIM.

2) Jika $\mathrm{H}_{0}$ ditolak berarti ada perbedaan kinerja keuangan Bank BUMN dan Bank Swasta Nasional pada tahun 2016-2019 dilihat dari ROA, ROE, CAR, dan NIM.

\section{Pada tahun 2016}

\section{a. Return On Asset (ROA)}

Dari perhitungan tersebut diperoleh hasil 1,2185. Maka nilai $t_{\text {hitung }}$ berada pada $-2,228 \leq 1,2185 \leq 2,228$. Maka dapat ditarik kesimpulan $\mathrm{H}_{0}$ diterima, bahwa tidak ada perbedaan kinerja keuangan Bank BUMN dan Bank Swasta Nasional dilihat dari ROA tahun 2016.

\section{b. Return On Equity (ROE)}

Dari perhitungan tersebut diperoleh hasil 0,1684. Maka nilai $t_{\text {hitung }}$ berada pada $-2,228 \leq 0,1684 \leq 2,228$. Maka dapat ditarik kesimpulan $\mathrm{H}_{0}$ diterima, bahwa tidak ada perbedaan kinerja keuangan Bank BUMN dan Bank Swasta Nasional dilihat dari ROE tahun 2016.

\section{c. Capital Adequacy Ratio (CAR)}

Dari perhitungan tersebut diperoleh hasil 1,1749. Maka nilai $t_{\text {hitung }}$ berada pada $-2,228 \leq 1,1749 \leq 2,228$. Maka dapat ditarik kesimpulan $\mathrm{H}_{0}$ diterima bahwa tidak ada perbedaan kinerja keuangan Bank BUMN dan Bank Swasta Nasional dilihat dari CAR tahun 2016.

\section{d. Net Interest Margin (NIM)}

Dari perhitungan tersebut diperoleh hasil 1,7489. Maka nilai $t_{\text {hitung }}$ berada pada $-2,228 \leq 1,7489 \leq 2,228$. Maka dapat ditarik kesimpulan $\mathrm{H}_{0}$ diterima bahwa tidak ada perbedaan kinerja keuangan Bank BUMN dan Bank Swasta Nasional dilihat dari NIM tahun 2016. 


\section{Pada tahun 2017}

\section{a. Return On Asset (ROA)}

Dari perhitungan tersebut diperoleh hasil 1,3196. Maka nilai $t_{\text {hitung }}$ berada pada $-2,228 \leq 1,3196 \leq 2,228$. Maka dapat ditarik kesimpulan $\mathrm{H}_{0}$ diterima, bahwa tidak ada perbedaan kinerja keuangan Bank BUMN dan Bank Swasta Nasional dilihat dari ROA tahun 2017.

\section{b. Return On Equity (ROE)}

Dari perhitungan tersebut diperoleh hasil 2,1784. maka nilai $t_{\text {hitung }}$ berada pada $-2,228 \leq 2,1784 \leq 2,228$. Maka dapat ditarik kesimpulan $\mathrm{H}_{0}$ diterima, bahwa tidak ada perbedaan kinerja keuangan Bank BUMN dan Bank Swasta Nasional dilihat dari ROE 2017.

\section{c. Capital Adequacy Ratio (CAR)}

Dari perhitungan tersebut diperoleh hasil 1,0225. Maka nilai $t_{\text {hitung }}$ berada pada $-2,228 \leq 1,0225 \leq 2,228$. Maka dapat ditarik kesimpulan $\mathrm{H}_{0}$ diterima bahwa tidak ada perbedaan kinerja keuangan Bank BUMN dan Bank Swasta Nasional dilihat dari CAR tahun 2017.

\section{d. Net Interest Margin (NIM)}

Dari perhitungan tersebut diperoleh hasil 1,4776. Maka nilai $t_{\text {hitung }}$ berada pada $-2,228 \leq 1,4776 \leq 2,228$. Maka dapat ditarik kesimpulan $\mathrm{H}_{0}$ diterima bahwa tidak ada perbedaan kinerja keuangan Bank BUMN dan Bank Swasta Nasional dilihat dari NIM tahun 2017.

\section{Pada tahun 2018}

\section{a. Return On Asset (ROA)}

Dari perhitungan tersebut diperoleh hasil 1,8261. Maka nilai $t_{\text {hitung }}$ berada pada $-2,228 \leq 1,8261 \leq 2,228$. Maka dapat ditarik kesimpulan $\mathrm{H}_{0}$ diterima, bahwa tidak ada perbedaan kinerja keuangan Bank BUMN dan Bank Swasta Nasional dilihat dari ROA tahun 2018.

\section{b. Return On Equity (ROE)}

Dari perhitungan tersebut diperoleh hasil 3,1567. Maka nilai $t_{\text {hitung }}$ berada pada3,1567> 2,228. Maka dapat ditarik kesimpulan $\mathrm{H}_{0}$ ditolak, bahwa 
ada perbedaan kinerja keuangan Bank BUMN dan Bank Swasta Nasional dilihat dari ROE 2018.

\section{c. Capital Adequacy Ratio (CAR)}

Dari perhitungan tersebut diperoleh hasil -0,1155. Maka nilai $t_{\text {hitung }}$ berada pada $-2,228 \leq-0,1155 \leq 2,228$. Maka dapat ditarik kesimpulan $\mathrm{H}_{0}$ diterima bahwa tidak ada perbedaan kinerja keuangan Bank BUMN dan Bank Swasta Nasional dilihat dari CAR tahun 2018.

\section{d. Net Interest Margin (NIM)}

Dari perhitungan tersebut diperoleh hasil 0,4993. Maka nilai $t_{\text {hitung }}$ berada pada $-2,228 \leq 0,4993 \leq 2,228$. Maka dapat ditarik kesimpulan $\mathrm{H}_{0}$ diterima bahwa tidak ada perbedaan kinerja keuangan Bank BUMN dan Bank Swasta Nasional dilihat dari NIM tahun 2018.

\section{Pada tahun 2019}

\section{a. Return On Asset (ROA)}

Dari perhitungan tersebut diperoleh hasil 1,6776.Maka nilai $t_{\text {hitung }}$ berada pada $-2,228 \leq 1,6776 \leq 2,228$. Maka dapat ditarik kesimpulan $\mathrm{H}_{0}$ diterima, bahwa tidak ada perbedaan kinerja keuangan Bank BUMN dan Bank Swasta Nasional dilihat dari ROA tahun 2019.

\section{b. Return On Equity (ROE)}

Dari perhitungan tersebut diperoleh hasil 0,5472. Maka nilai $t_{\text {hitung }}$ berada pada $-2,228 \leq 0,5472 \leq 2,228$. Maka dapat ditarik kesimpulan $\mathrm{H}_{0}$ diterima, bahwa tidak ada perbedaan kinerja keuangan Bank BUMN dan Bank Swasta Nasional dilihat dari ROE 2019.

\section{c. Capital Adequacy Ratio (CAR)}

Dari perhitungan tersebut diperoleh hasil -0,3383. Maka nilai $t_{\text {hitung }}$ berada pada $-2,228 \leq-0,3383 \leq 2,228$. Maka dapat ditarik kesimpulan $\mathrm{H}_{0}$ diterima bahwa tidak ada perbedaan kinerja keuangan Bank BUMN dan Bank Swasta Nasional dilihat dari CAR tahun 2019.

\section{d. Net Interest Margin (NIM)}

Dari perhitungan tersebut diperoleh hasil 1,7122. Maka nilai $t_{\text {hitung }}$ berada pada $-2,228 \leq 1,7122 \leq 2,228$. Maka dapat ditarik kesimpulan $\mathrm{H}_{0}$ 


$\begin{array}{ll}\text { ISSN Cetak } & : 2087-0434 \\ \text { E-ISSN } & : 2599-0810\end{array}$

diterima bahwa tidak ada perbedaan kinerja keuangan Bank BUMN dan Bank Swasta Nasional dilihat dari NIM tahun 2019.

\section{KESIMPULAN}

Berdasarkan hasil analisis yang telah diuraikan di atas, maka dapat ditarik kesimpulan yaitu :

1. Tidak terdapat perbedaan yang signifikan antara kinerja keuangan Bank BUMN dan Bank Swasta Nasional dilihat dari ROA tahun 2016-2019.

2. Tidak terdapat perbedaan yang signifikan antara kinerja keuangan Bank BUMN dan Bank Swasta Nasional dilihat dari ROE tahun 2016, 2017, dan 2019

3. Terdapat perbedaan yang signifikan antara kinerja keuangan Bank BUMN dan Bank Swasta Nasional dilihat dari ROE tahun 2018.

4. Tidak terdapat perbedaan yang signifikan antara kinerja keuangan Bank BUMN dan Bank Swasta Nasional dilihat dari CAR tahun 2016-2019.

5. Tidak terdapat perbedaan yang signifikan antara kinerja keuangan Bank BUMN dan Bank Swasta Nasional dilihat dari NIM tahun 2016-2019

\section{DAFTAR REFERENSI}

Abdullah, Ridwan. (2013). Inovasi Pembelajaran. Jakarta: Bumi Aksara

Amstrong, Michael, (1998), Manajemen Sumber Daya Manusia. Jakarta: Gramedia

Anita, N. (2016). Analisis Perbandingan Kinerja Keuangan Bank Pemerintah (BUMN) dan Bank Swasta Nasional yang Terdaftar di Bursa Efek Indonesia (BEI) (Doctoral dissertation, Universitas Islam Negeri Alauddin Makassar).

Anonim Undang-Undang No. 10 Tahun 1998, Tentang Perbankan, Bank Indonesia, Jakarta.

Arikunto, Suharsimi. 2002. Prosedur Penelitian Suatu Pendekatan Praktek, Edisi Revisi, Rineka Cipta, Jakarta.

Arista, Desy dan Astohar.2012. Analisis Faktor-Faktor yang Mempengaruhi Return Saham (Kasus pada Perusahaan Manufaktur yang Go Public di BEI periode tahun 2005 2009).Jurnal Ilmu Manajemen dan Akuntansi Terapan, Vol. 3, No. 1, Hal. 1 - 15.

Bastian, Indra, (2001), Akuntansi Sektor Publik. Yogyakarta: PPA FE UGM 
ISSN Cetak : 2087-0434

E-ISSN : $\quad$ 2599-0810

Helfert, (1999), Teknik Analisis Keuangan. Terjemahan, Jakarta: Erlangga

Ikatan Akuntansi Indonesia, (1999), Standar Akuntansi Keuangan. Jakarta: STIE YKPN

Maharani, Vivi Putri, dan Chairil Afandy, Analisis Perbandingan Bank Pemerintah dan Bank Swasta terdaftar di Bursa Efek Indonesia, Skripsi Bengkulu: Program Studi Manajemen Fakultas Ekonomi Universitas Bengkulu, 2012

Mardiasmo, (2002), Akuntansi Sektor Publik. Yogyakarta: Andi Offset

Marmono Singgih dan Prihatini, Dewi, (2000), Penilaian Kinerja (Keuangan) Perusahaan.Diklat Manjemen Investasi, MM universitas Jember

Munawir, S, (2001), Analisis Laporan Keuangan. Edisi Keempat, Cetakan Ke 12, Yogyakarta: Liberty

Nazir, Moh. (2013). Metode Penelitian. Bogor: Ghalia Indonesia.

Pandia, Frianto. 2012. Manajemen Dana dan Kesehatan Bank. Jakarta: Penerbit Rineka Cipta

Prastowo, Dwi dan Rifka Juliyanty, (2002), Analisis Laporan Keuangan , Konsep, Dan Aplikasinya. Yogyakarta: UPP AMP YKPN

Riyanto, Bambang, (1995), Dasar-Dasar Pembelanjaan Perusahaan. Yogyakarta: BPFE

Siamat, Dahlan Manajemen Lembaga Keuangan, Solo: Intermedia, 1995

Sudjana, Nana dan Ibrahim.(2004).Penelitian Dan Penilaian Pendidikan, Bandung : Sinar Baru Algensindo

Sugiyono. 2015. Metode Penelitian Kuantitatif. Kualitatif dan R\&D. Bandung Alfabeta.

Sugiyono. 2009. Metode Penelitian Kuantitatif. Kualitatif dan R\&D. Bandung Alfabeta.

Sugiyono. 2011. Metode Penelitian Kombinasi. Bandung:Alfabeta,

Sumber : $\underline{\text { http://www.ojk.go.id }}$

Thalib, D. (2016). Intermediasi, Struktur Modal, Efesiensi, Permodalan dan Risiko Terhadap Profitabilitas Bank. Jurnal Keuangan \& Perbankan, XX (1). 116-126

Theis, R. (2016). Perbandingan Kinerja Keuangan Bank Umum Pemerintah dan Bank Swasta Nasional (Devisa) yang Go Public di BEI (Periode 2010-2014). Jurnal Berkala Ilmiah Efisiensi, 16(1).

Undang - Undang RI Nomor 10 Tahun 1998 tanggal 10 November. Tentang Jenis-Jenis Bank. 